\title{
Analisa Risiko Proses Pengapungan Kembali pada Kapal Tenggelam di Perairan Tanjung Perak
}

\author{
Muhammad Wildan Firdaus dan Heri Supomo \\ Departemen Teknik Perkapalan, Fakultas Teknologi Kelautan, Institut Teknologi Sepuluh Nopember (ITS) \\ e-mail: hsupomo@na.its.ac.id ;
}

\begin{abstract}
Abstrak - Salah satu penyebab kecelakaan di laut adalah kapal tenggelam. Kapal tenggelam membutuhkan tindakan penyelamatan, baik untuk menyelamatkan kapal ataupun untuk pembersihan alur pelayaran. Pekerjaan pada industri salvage sangatlah berisiko tinggi, hal tersebut dikarenakan kondisi perairan sulit untuk dilewati, faktor keamanan peralatan, hingga risiko yang diakibatkan dari kapal itu sendiri. Untuk mengidentifikasi risiko pada pekerjaan pengapungan kapal tenggelam digunakan framework untuk mengetahui bagian pekerjaan yang berisiko. Pada Framework tersebut digunakan pendekatan Fault Tree Analysis dan Checklist. Akar permasalah dari risiko diberikan penilaian untuk mengetahui tingkat risiko dari masing-masing risiko. Penilaian dilakukan dengan memberikan skala 1 sampai 5 pada dampak yang dihasilkan dan tingkat kemungkinannya pada variasi lama tenggelam kapal. Penilaian dilakukan dengan kuisioner yang diberikan pada ahli yang berpengalaman dibidangnya. Risk Priority Number diberikan untuk mengetahui tingkat risiko kegagalan proses pada lama tenggelamnya kapal di bawah 10 tahun dan di atas 10 tahun. Masing-masing risiko diberikan mitigasi berupa rekomendasi tindakan preventif. Penambahan biaya yang dihasilkan dari tindakan preventif yang diberikan sebesar $4,98 \%$ untuk kapal dengan lama tenggelam dibawah 10 tahun dan $5,58 \%$ untuk kapal dengan lama tenggelam diatas 10 tahun. Strategi implementasi RBI merupakan cara yang efektif untuk mengidentifikasi biaya tambahan, biaya tak terduga dan risiko yang terlibat dalam pekerjaan pengapungan kapal tenggelam. Oleh karena itu, perencanaan biaya pekerjaan pengapungan kapal dapat dilakukan dengan cara yang lebih akurat.
\end{abstract}

Kata kunci-Biaya Mitigasi, Pengapungan Kapal Tenggelam, Risk Based Inspection (RBI).

\section{PENDAHULUAN}

$\mathrm{K}$ EBUTUHAN alat transportasi di bidang maritim sangat diperlukan bagi negara indonesia sebagai negara maritim dengan luas wilayah laut terbesar di dunia dan garis pantai terpanjang kedua di dunia. Dengan banyaknya jumlah kapal yang berada diperairan Indonesia sangat memungkinkan untuk terjadinya kecelakaan kapal. Kecelakaan kapal dapat terjadi karena faktor iklim dan cuaca serta faktor teknis ataupun human error. Banyaknya kecelakaan kapal di daerah perairan Indonesia membuat industri salvage di Indonesia sangatlah berperan penting dalam penanganan pada kecelakaan kapal sebagai alat bantu penyelamatan kapal atau pengangkatan kapal tenggelam. Jumlah kapal yang tenggelam pada Perairan Tanjung Perak cukup banyak dan beragam jenisnya, serta bermacam-macam jenis kecelakaan yang dihadapi, mulai dari tabrakan antar kapal, bocornya lambung karena menabrak karang, terbaliknya kapal akibat kelebihan muatan hingga cuaca yang buruk atau gelombang yang tinggi.

Pekerjaan pada industri salvage sangatlah berisiko tinggi. Hal tersebut dikarenakan kondisi perairan sulit untuk dilewati, faktor keamanan peralatan, hingga risiko yang diakibatkan dari kapal itu sendiri [1]. Dengan banyaknya peralatan dan proses yang dilakukan pada pekerjaan pengapungan kembali, maka risiko yang dihadapi semakin besar dan beragam. Berbagai macam jenis kapal yang tenggelam juga dapat menambah risiko yang dihadapi, contohnya ketika kapal yang mengangkut bahan yang mudah terbakar, maka risiko terjadinya ledakan pada proses pengangkatan sangat mungkin terjadi. Proses pengangkatan kapal merupakan pekerjaan yang menggunakan peralatan yang memiliki risiko tinggi dan ahli dibidangnya sehingga pengoperasiannya butuh keahlian dan prosedur yang baik [2]. Risiko yang dihadapi pada saat proses pengapungan kembali kapal, yaitu mulai dari kerusakan pada peralatan, keterlambatan pekerjaan hingga kehilangan nyawa. Oleh karena itu, risiko pada proses pekerjaan pengapungan kembali kapal yang tenggelam harus dianalisa dengan menggunakan FTA untuk mengetahui akar permasalahannya [3]. Risiko yang telah diketahui maka diberi tindakan preventif agar risiko tersebut dapat ditekan ataupun dicegah sehingga biaya yang direncanakan dapat lebih akurat [4].

\section{URAIAN PENELITIAN}

Uraian penelitian ini menjelaskan bagaimana langkahlangkah sistematis yang harus dilakukan dalam menyelesaikan Studi. Penelitian Studi ini terdiri dari beberapa tahap, yaitu tahap persiapan, tahap pengumpulan dan pengolahan data, tahap analisa dan pembahasan, serta tahap penarikan kesimpulan dan saran.

Tahap pertama adalah tahap persiapan yang meliputi kegiatan identifikasi dan perumusan masalah, serta studi penelitian yang terdiri dari studi pustaka dan studi lapangan. Tahapan kedua adalah pengumpulan dan pengolahan data yang meliputi kegiatan identifikasi informasi teknis salvage, kondisi existing kapal tenggelam dan biaya proses pengapungan. Tahap berikutnya adalah analisa perencanaan yang meliputi proses perencanaan biaya pengapungan kapal dengan mengidentifikasi terlebih dahulu risiko yang ada pada proses pekerjaan, setelah itu risiko yang didapatkan dicari akar permasalahannya dan diberi penilaian tingkat risiko, lalu risiko diberi tindakan preventif dan penambahan biaya yang diberikan pada tindakan preventif tersebut. Tahapan selanjutnya adalah analisa dan pembahasan yang meliputi kegiatan analisa hasil 
dari tahap sebelumnya dan dilakukan pembahasan lebih lanjut yaitu adalah analisa risiko pada proses pengapungan kapal tenggelam. Tahap terakhir yaitu tahap empat yang merupakan penarikan kesimpulan dan saran, pada tahap ini meliputi kegiatan penarikan kesimpulan sesuai dengan tujuan awal dan saran dari hasil penelitian.

\section{A. Identifikasi Masalah}

Pada tahap ini dilakukan identifikasi yang bertujuan untuk mengetahui dan memahami pokok permasalahan yang dijadikan objek penelitian yaitu analisa risiko Proses Pengapungan kembali pada kapal tenggelam di perairan tanjung perak. Pada tahap ini juga ditetapkan tujuan dari penelitian.

\section{B. Studi Lapangan}

Studi lapangan diperlukan untuk mengetahui kondisi asli dilapangan agar dapat diaplikasikan kedalam pekerjaan studi yang mengambil topik tentang Analisa Proses Pengapungan Kembali Pada Kapal Tenggelam. Studi lapangan diperlukan untuk memberikan pemaham yang lebih dalam memahami proses pengapungan kembali pada kapal tenggelam. Proses ini bertujuan untuk mengetahui kondisi kapal tenggelam yang ada di Tanjung Perak, metode yang digunakan dalam pengapungan kapal, SOP yang digunakan serta pengaruhnya terhadap lalulintas laut.

\section{Studi Kepustakaan}

Setelah dilakukan penentuan rumusan masalah dan tujuan penelitian kemudian dilakukan studi literatur yang terkait dengan penelitian Studi ini. Penggunaan studi literatur bertujuan untuk memberikan pemahaman lebih dalam mengenai konsep penelitian yang akan dilakukan. Studi literatur diarahkan pada kajian terhadap objek penelitian melalui beberepa literatur seperti buku, jurnal, penelitian terdahulu terkait manajemen risiko dan proses pengapungan kapal tenggelam.

\section{Perencanaan Biaya Proses Pengapungan Kembali}

Tahap perencanaan biaya proses pengapungan kembali ini sangat penting untuk dilakukan karena berkaitan dengan kelanjutan daripada penelitian. Pada tahap ini dilakukannya identifikasi risiko pada pekerjaan pengapungan kapal. Setelah risiko diketahui maka dicari akar pemasalahan dari masingmasing risiko dan diberikan penilaian tingkat risiko sehingga diketahui risiko dengan tingkat rendah hingga tinggi. Lalu risiko diberikan tindakan preventif dimana biaya yang dikeluarkan untuk tindakan preventif tersebut ditambahkan pada biaya pengapungan kapal tenggelam.

\section{E. Tahap Analisa dan Pembahasan}

Pada tahap ini adalah dilakukannya analisa dari hasil yang didapatkan pada perencanaan biaya apakah risiko dapat memperlancar proses pengapungan, pengaruhnya terhadap aspek ekonomis, dapat mengurangi dampak yang diakibatkannya. Pembahasan rekomendasi solusi ini dapat dilakukan dengan diskusi dengan pihak-pihak yang dianggap expert dibidangnya.

\section{F. Tahap Penarikan Kesimpulan}

Tahap penarikan kesimpulan dan saran adalah tahapan terakhir dalam penelitian studi ini. Kesimpulan yang ditarik nantinya dapat menjawab tujuan dari penelitian studi ini. Sedangkan saran diberikan untuk perbaikan penelitian selanjutnya.

\section{ANALISA DAN PEMBAHASAN}

\section{A. Kondisi Existing}

Pelabuhan Tanjung Perak adalah pintu gerbang Indonesia untuk provinsi jawa timur yang menjadi pusat kolektor dan distributor ke kawasan timur Indonesia. Letaknya yang strategis menjadikan Pelabuhan Tanjung Perak menjadi pusat pelayaran terinsulair kawasan timur Indonesia. Pelabuhan tanjung perak dilewati oleh alur pelayaran barat Surabaya. Pasca revitalisasi yang dilakukan di alur pelayaran barat Surabaya yang dulunya hanya bisa dilalui kapal-kapal dengan besar 15 ribu DWT pasca revitalisasi kapal-kapal yang masuk bias mencapai 80 ribu DWT. Kedalaman jalur APBS yang sebelumnya hanya -9 meter dan lebar 100 meter pasca revitalisasi menjadi 13 meter dengan lebar mencapai 150 meter. Kedalaman dan lebar laut di pelabuhan tanjung perak cukup beragam pada masing-masing terminalnya. Untuk kedalaman yang paling kecil berada pada terminal kalimas yaitu hanya 2,5 meter kedalamannya. Kedalaman yang paling dalam berada pada dermaga internasional yaitu sebesar 10,5 meter. Lebar yang dimiliki juga bervariasi yaitu mulai dari 15 meter hingga mencapai 50 meter. Pada pelabuhan tanjung perak juga terdapat kendala-kendala yang menyebabkan kapal mengalami kecelakaan, antara lain:

1. Gosong pasir (bentukan daratan yang menonjol ke permukaan)

2. Keberadaan ranjau laut sisa penjajahan jepang

3. Keberadaan kerangka kapal sisa penjajahan jepang

4. Keberadaan kerangka baru akibat kecelakaan

5. Keberadaan pipa bawah laut

Dari 35 bangkai kapal yang ada di perairan Tanjung Perak, jumlah kapal kargo yang tenggelam sebesar $26 \%$ atau berjumlah 9 buah. Kapal muatan yang tenggelam sejumlah $26 \%$ sama dengan jumlah kapal kargo. Masing-masing lainnya yaitu kapal tanker, keruk, penumpang, penumpang \& muatan, ponton serta potongan-potongan bangkai berjumlah $48 \%$, dengan rincian kapal penumpang 6\%, kapal tanker $3 \%$, ponton $3 \%$, keruk 3\%, keruk dan muatan $8 \%$ dan dumping ground $8 \%$. Semua ini adalah kapal-kapal yang telah tenggelam di perairan Tanjung Perak. Dari gambar diketahui persentase terbesar berasal dari kapal kargo dan kapal muatan yang berjumlah 52\% dari total keseluruhan kapal tenggelam. Dan yang terkecil adalah kapal tanker, ponton, dan kapal keruk yang masingmasing berjumlah 1 buah atau 3\% dari total keseluruhan kapal. 


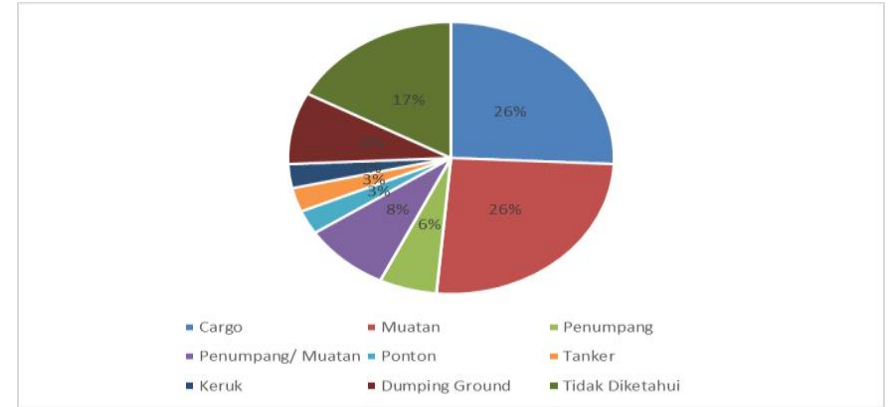

Gambar 1. Persentase Jenis Kapal Tenggelam

Pada Gambar 1 dijelaskan untuk melakukan pekerjaan pengapungan kembali pada kapal tenggelam maka perlu dilakukan investigasi pada kapal kerangka kapal yang akan diapungkan. Pekerjaan investgasi atau survey dilakukan untuk mengetahui keberadaan kapal atau kondisi kapal saat didasar perairan. Pada proses pekerjaan ini dilakukan dengan menggunakan tenaga penyelam antara lain untuk mengetahui :

1. Letak koordinat/posisi keberadaan kapal

2. Kondisi dan keadaan kerangka kapal di dasar laut

3. Dimensi kapal

4. Kedalaman air dilokasi

5. Kecepatan arus pasang surut di lokasi pekerjaan

6. Mengetahui kondisi kapal dilakukan secara manual dengan menggunakan penyelam. Penyelam akan mengukur dimensi kapal, kedalaman kerangka, posisi tenggelam serta memeriksa tingkat korosi dari kerangka kapal

7. Mengetahui koordinat letak dari kerangka kapal menggunakan GPS

Dalam proses penyelamatan kapal ditemukan berbagai macam kendala yang dapat menghambat proses penyelamatan, urusan birokrasi yang berbelit-belit menjadi pokok permasalahan. Maka untuk mengetahui akar permasalahan tersebut perlu dikaji lagi inti dari masalah tersebut. maka untuk mengetahui masalah tersebut maka kita harus melihat kembali undang-undang nomor 17 tahun 2008, undang-undang tersebut adalah undang-undang yang berhubungan dengan bisnis penyelamatan kapal.

Berdasarkan hasil wawancara dari salah satu narasumber maka dari hari pertama terhitung kapal tenggelam sampai 180 hari maka apabila kapal tersebut tidak dilakukan pengangkatan, kapal tersebut menjadi milik pemerintah. Hal tersebut juga dinyatakan dalam pasal 203 ayat 1: pemilik kapal wajib menyingkirkan kerangka kapal dan/atau muatannya yang mengganggu keselamatan dan keamanan pelayaran paling lama 180 (seratus delapan puluh) hari kalender sejak kapal tenggelam. Akan tetapi dalam kondisi aslinya pemilik kapal jarang sekali mengangkat kapalnya yang tenggelam dan mengganggu alur pelayaran. Para pemilik kapal yang tenggelam melihat celah pada pasal 203 ayat 2 yang menyatakan: pemerintah wajib mengangkat, menyingkirkan, atau menghancurkan seluru atau sebagian dari kerangka kapal dan/atau muatannya atas biaya pemilik apabila dalam batas waktu yang ditetapkan pemerintah, pemilik tidak melaksanakan tanggung jawab dan kewajibannya sebagaimana dimaksud pada ayat (1). Pasal tersebut menjadi celah bagi para pemilik kapal untuk dapat lari dari tanggung jawab mereka sebagai pemilik kapal.

\section{B. Pendekatan RBI}

Jenis penilaian pada RBI dapat dilakukan dengan 3 cara yaitu pendekatan kualitatif, semi kuantitatif dan pendekatan kuantitatif. Setiap pendekatan menghasilkan cara sistematik untuk menyaring risiko. Pada studi ini penilaian risiko dilakukan dengan penilaian kualitatif, yaitu penilaian yang dilakukan dengan pendekatan secara kualitatif. Pendekatan kualitatif cocok untuk studi implementasi sebuah masalah. Untuk penilaian risiko dilakukan bedasarkan pengalaman ahli. Hal pertama yang dilakukan untuk pendekatan RBI adalah dengan melakukan penerapan FTA untuk mengidentifikasi risiko yang terjadi pada proses pekerjaan.

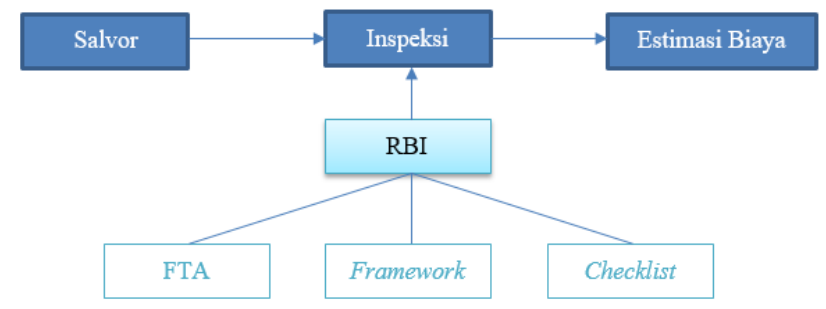

Gambar 2. Alur Pendekatan RBI

Pada Gambar 2 diketahui hal pertama yang dilakukan adalah identifikasi risiko dengan menggunakan FTA untuk mengidentifikasi risiko apa saja yang terdapat pada proses pengapungan kapal tenggelam. Setelah identifikasi dilakukan, implementasikan RBI adalah langkah selanjutnya. Untuk mengimplementasikan RBI maka dibutuhkan bantuan framework dan checklist. Framework memiliki alur risiko dalam prosesnya, dalam proses checklist identifikasi dan mitigasi yang dilakukan untuk mengantisipasi risiko.

\section{Framework}

Framework (kerangka kerja) adalah kumpulan prosedurprosedur pada sebuah proses untuk tujuan tertentu yang sudah siap digunakan, sehingga mempermudah pekerjaan seseorang tanpa harus membuat fungsi atau urutan kerja dari awal pekerjaan. Kerangka kerja membuat pekerjaan lebih tertata dan terorganisir sehingga dalam mendeteksi sebuah kesalahan menjadi lebih mudah. Framework merupakan pondasi awal sebuah pekerjaan untuk menentukan pekerjaan apa yang akan dikerjakan. Pertama tentukan dahulu pekerjaan yang ingin diidentifikasi, lalu terapkan prosesnya dengan framework. Tanpa framework kita akan kesulitan dalam membuat program kerja. Beberapa alasan mengapa memilih untuk menggunakan framework :

1. Mempermudah pembangunan sebuah proses kerja

2. Memudahkan proses maintenance karena sudah ada pola tertentu dalam framework

3. Lebih bebas dalam pengembangannya 


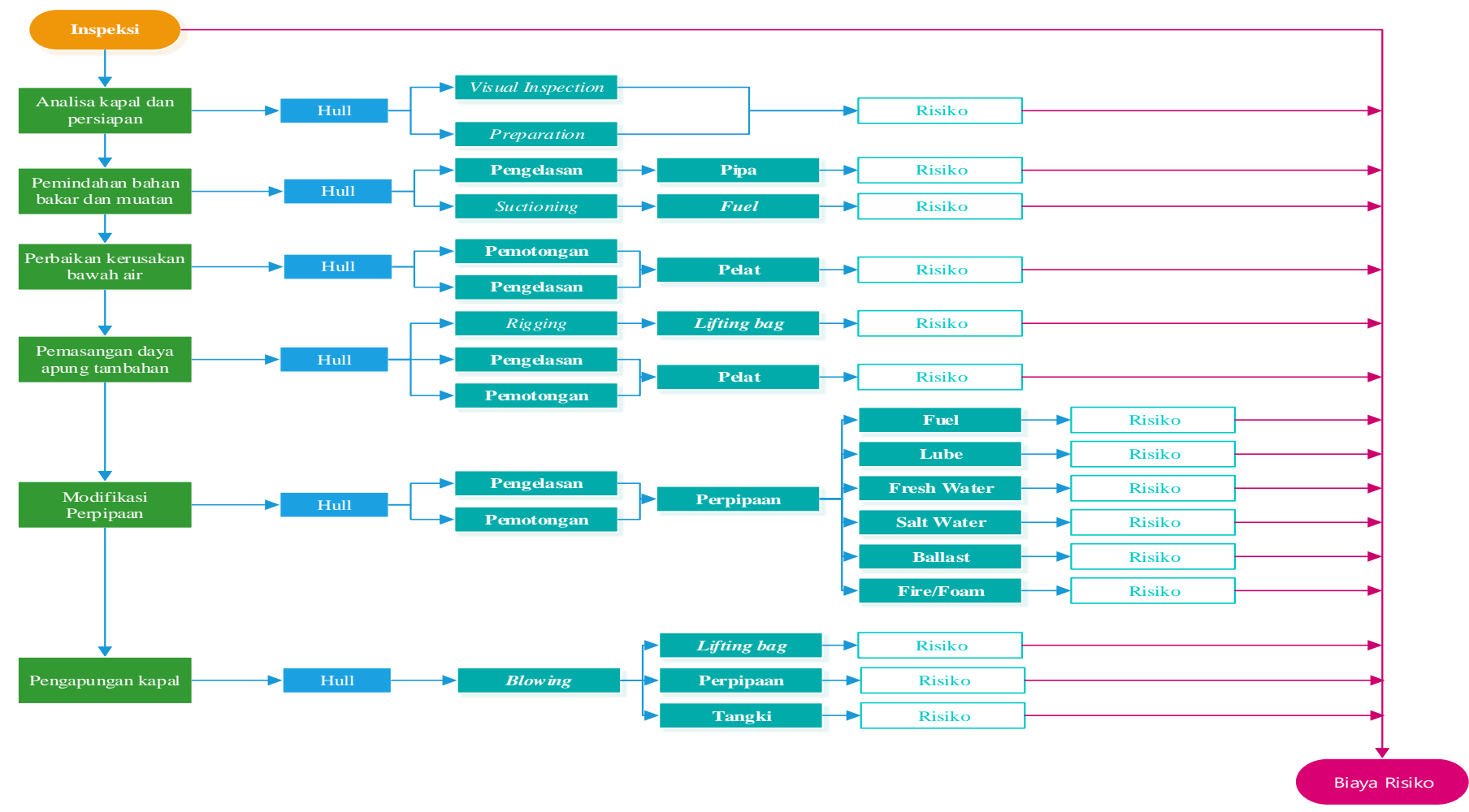

Gambar 3. Framework Pengapungan Kapal

Pada Gambar 3 proses pekerjaan dimulai dengan inspeksi yang bertujuan untuk mengetahui bagaimana kondisi kapal tenggelam yang akan diangkat. Setelah itu dipersiapkan segala macam kebutuhan yang diperlukan pada proses pekerjaan. Pada proses ini risiko terjadi ketika proses inspeksi kondisi kapal tidak tepat maka proses perencanaan kebutuhan tidak sesuai dengan keperluan. Proses selanjutnya adalah pemindahan bahan bakar dan muatan. Pada proses ini risiko dapat terjadi saat pemindahan bahan bakar yang melibatkan bahan kimia. Bahan kimia dapat memicu terjadinya kebakaran. Proses selanjutnya yaitu memperbaiki kerusakan yang terdapat pada lambung kapal. Dalam proses ini terdapat pekerjaan replating yang dilakukan di dalam air yang berisiko.

Selanjutnya adalah proses pemasangan daya apung tambhan yang berupa air bag. Proses ini berisiko karena suatu saat kapal dapat terbalik dengan tiba-tiba karena penempatan airbag yang tidak sesuai sehingga membuat kapal terbalik. Sehingga membuat badan kapal patah ataupun menimpa penyelam. Langkah selanjutnya adalah dengan memodifikasi perpipaan yang akan difungsikan sebagai daya apung tambahan bagi kapal. Dalam proses ini juga terdapat risiko terbaliknya kapal karena arus laut yang kencang.sehingga menyebabkan badan kapal apatah atupun menimpa operator. Proses pengapungan kapal dilakukan dengan meniupkan udara kedalam lambung kapal yang telah dibuat kedap.

Peniupan udara juga dilakukan pada air bag yang telah dipasang dan tangka-tangki kapal yang telah dimodifikasi sebagai daya apung tambahan. Dalam proses ini banyak risiko yang dapat membuat terjadinya kegagalan. Risiko yang terdapat pada proses pengapungan mulai dari kapal terjatuh karena terjadi kebocoran pada tangki sehingga udara yang ditiupkan menjadi keluar. Kerusakan peralatan juga dapat menjadi sumber kegagalan apabila kompresor tiba-tiba mengalami kerusakan. Kapal yang tiba-tiba terangkat dengan cepat atau terbalik juga menjadi sumber risiko yang ada pada pekerjaan pengapungan kapal. Dalam kerangka kerja kita dapat mengetahui bagian-bagian yang berisiko dari sistem pekerjaan.

\section{Fault Tree Analysis}

Fault Tree Analysis adalah suatu teknik yang digunakan untuk mengidentifikasi risiko yang berperan terhadap terjadinya suatu kegagalan. Metode ini dilakukan dengan pendekatan yang bersifat top down, yang diawali dengan asumsi kegagalan atau kerugian dari kejadian puncak (top event) kemudian merinci sebab-sebab mengapa top event terjadi sampai pada suatu kegagalan dasar (root cause). FTA merupakan teknik untuk mengidentifikasi kegagalan (failure) dari suatu sistem yang berorientasi pada fungsi atau lebih dikenal dengan top down approach karena analisa ini berawal dari sistem level (top) dan meneruskannya ke bawah.

\section{E. Probability of Failure}

Pada proses pengapungan kapal tenggelam diijelaskan bahwa tingkatan kemungkinan yang terjadi mulai dari sangat jarang hingga kemungkinan yang sangat besar/hampir pasti terjadi. Kemungkinan terjadinya risiko bedasarkan tingkat terjadinya risiko dalam 5 kali pekerjaan, mulai dari terjadi kurang dari satu kejadian dalam 5 kali proses pekerjaan hingga terjadi 5 kali dalam 5 proses pengapungan. Dalam indeks frekuensi juga dijelaskan tingkat kemungkinan terjadinya risiko mulai dari $1 \%-10 \%, 10,1 \%-25 \%, 25,1 \%-50 \%, 50,1 \%-75 \%$ sampai $75,1 \%-100 \%$. 


\section{F. Consequence of Failure}

Tabel 1.

Kriteria Consequence

\begin{tabular}{|c|c|c|c|}
\hline \multicolumn{2}{|c|}{ Dampak/Severity } & \multicolumn{2}{|c|}{ keterangan } \\
\hline skala & kriteria & kriteria severity & Indeks Frekuensi Kuantitatif \\
\hline 1 & sangat rendah & tidak menimbulkan kerugian & Tingkat kerugian 0\% \\
\hline 2 & rendah & kerugian $\leq \mathrm{Rp} .2,5 \mathrm{M}$ & Tingkat kerugian $\leq 20 \%$ \\
\hline 3 & sedang & kerugian $>$ Rp.2,5M - Rp.5 M & Tingkat kerugian $>20 \%-40 \%$ \\
\hline 4 & tinggi & kerugian $>$ Rp.5 M - Rp. $10 \mathrm{M}$ & Tingkat kerugian $>40 \%-80 \%$ \\
\hline 5 & sangat tinggi & kerugian $>$ Rp.10M & Tingkat kerugian diatas $80 \%$ \\
\hline
\end{tabular}

Pada Tabel 1 dapat dilihat bahwa kriteria dari konsekuensi yang ditimbulkan mulai dari sangat rendah, rendah, sedang, tinggi hingga sangat tinggi. Dalam penilaiannya kriteria konsekuensi dilakukan bedasarkan pekerjaan salah satu perusahaan salvage. Untuk kategori sangat rendah tidak ada kerugian yang ditimbulkan. Untuk kategori rendah lebih kecil sama dengan Rp. 2,5 M, dan untuk kategori sedang kerugian yang didapatkan lebih besar dari Rp.2,5 M sampai Rp.5 M. Untuk kegian diantara Rp. 5 M sampai dengan Rp. 10 M maka kerugian masuk dalam kategori tinggi. Sedangkan untuk kerugian diatas $10 \mathrm{M}$ maka dampak yang ditimbulkan sangat tinggi.

\section{G. Evaluasi Risiko}

Pada evaluasi risiko tingkat keparahan yang dihasilkan mengacu pada Tabel sedangkan untuk tingkat kemungkinan/probabilitas dibagi menjadi 5 yaitu sangat kecil, kecil, sedang, besar dan sangat besar. Dan untuk tingkat keparahan dibagi menjadi 5 yaitu insignificant, minor, moderate, major, critical/katastropik. Setelah penilaian risiko mana hasilnya dapat disajikan dengan matrik risiko agar lebih mudah dipahami dan lebih sederhana. Berikut adalah matriks risiko dari penilaian risiko proses pengapungan kapal tenggelam.

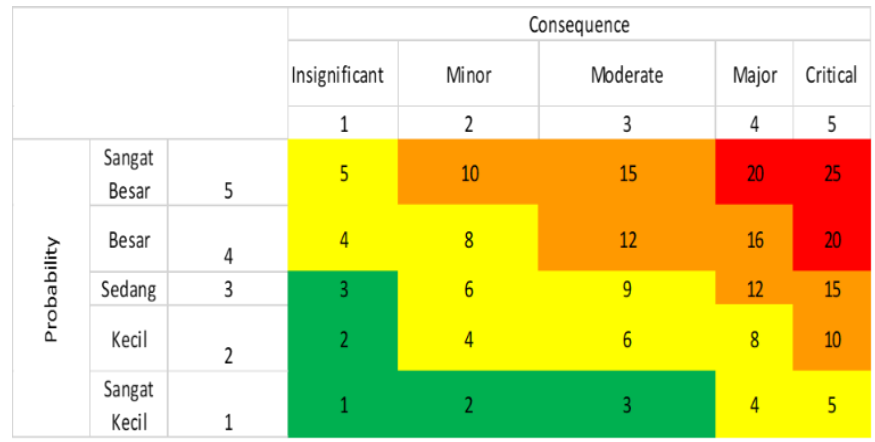

Gambar 4. Peta Matriks Risiko

Pada Gambar 4 risiko yang berada dalam warna hijau atau risiko dengan tingkat rendah memiliki nilai besaran 1 sampai 3 . Sedangkan untuk risiko dengan warna kuning atau risiko dengan tingkat risiko menengah memiliki nilai 4 sampai 9 . Untuk risiko tinggi atau yang berwarna orange memiliki nilai besaran 10 sampai 16 . Risiko dengan tingkat sangat tinggi memiliki nilai besaran 10 sampai 25 . Besaran nilai yang berada pada masing-masing kotak berasal dari perkalian antara tingkat kemungkinan terjadinya risiko dengan tingkat keparahan yang dihasilkan risiko.
Tabel 2 .

Risk Acceptable

Risk Acceptable

\begin{tabular}{|c|c|c|}
\hline \multicolumn{3}{|c|}{ Risk Acceptable } \\
\hline Level Risiko & \multicolumn{2}{|c|}{ Kriteria Untuk Manajemen Risiko } \\
\hline $1-3$ & Dapat Diterima & $\begin{array}{c}\text { Lakukan pengendalian yang } \\
\text { cukup }\end{array}$ \\
\hline $4-9$ & $\begin{array}{c}\text { Dilakukan } \\
\text { Pemantauan }\end{array}$ & $\begin{array}{c}\text { Diberikan tindakan preventif } \\
\text { (pencegahan) }\end{array}$ \\
\hline $10-16$ & $\begin{array}{c}\text { Dilakukan } \\
\text { Pemantauan }\end{array}$ & $\begin{array}{c}\text { Diberikan tindakan preventif } \\
\text { (pencegahan) }\end{array}$ \\
\hline $20-25$ & $\begin{array}{c}\text { Tidak Dapat } \\
\text { Diterima }\end{array}$ & $\begin{array}{c}\text { Diberikan tindakan preventif } \\
\text { (pencegahan) }\end{array}$ \\
\hline
\end{tabular}

Pada Tabel 2 dijelaskan suatu proses evaluasi risiko dimana risiko tersebut dapat diterima mana risiko yang tidak dapat diterima. Biasanya suatu organisasi akan menentukan risiko mana yang dapat diterima dan risiko mana yang harus diberikan pengendalian ataupun pencegahan. Evaluasi risiko dalam tabel dibagi menjadi 4 bagian yaitu dapat diterima, dilakukan pemantauan dan tidak dapat diterima.

\section{H. Mitigasi}

Upaya untuk mengurangi dampak yang dihasilkan dari risiko yang dihadapi merupakan bentuk dari mitigasi. Pada proses pengapungan kapal didapatkan beberapa risiko yang dihadapi seperti kapal terbalik, kapal terbakar, badan kapal patah dan kapal terjatuh. Dari beberapa risiko tersebut terdapat beberapa hal yang mendasarinya. Maka dari itu untuk mengurangi tingkat risiko tersebut dilakukan mitigasi. Mitigasi dilakukan untuk mengurangi dampak yang dihasilkan risiko. Tentu saja ketika melakukan mitigasi maka terdapat biaya-biaya yang dikeluarkan. Berikut tindakan preventif yangg dilakukan pada proses pengapungan kapal tengggelam.

Tabel 3.

Mitigasi

\begin{tabular}{|c|c|c|c|}
\hline No & Kondisi Existing & Akar Permasalahan & Tindakan Preventif \\
\hline 1 & $\begin{array}{l}\text { kurangnya jumlah } \\
\text { penyelam }\end{array}$ & $\begin{array}{l}\text { kesalahan analisa } \\
\text { kondisi kerusakan } \\
\text { kapal }\end{array}$ & $\begin{array}{l}\text { penambahan } \\
\text { jumlah penyelam } \\
\text { untuk memastikan } \\
\text { kondisi kerusakan } \\
\text { kapal }\end{array}$ \\
\hline 2 & $\begin{array}{l}\text { kurangnya tenaga } \\
\text { salvage master yang } \\
\text { berpengalaman }\end{array}$ & $\begin{array}{l}\text { kesalahan } \\
\text { perencanaan } \\
\text { kebutuhan material } \\
\text { \& komponen }\end{array}$ & $\begin{array}{l}\text { salvage master } \\
\text { harus } \\
\text { berpengalaman }\end{array}$ \\
\hline 3 & $\begin{array}{l}\text { kurangnya } \\
\text { penggunaan SDM } \\
\text { yang memiliki } \\
\text { kompetensi }\end{array}$ & $\begin{array}{l}\text { kekurangan SDM } \\
\text { yang memenuhi } \\
\text { kompetensi yang } \\
\text { dibutuhkan }\end{array}$ & $\begin{array}{l}\text { menggunakan jasa } \\
\text { operator sesuai } \\
\text { SDM yang } \\
\text { dibutuhkan } \\
\text { dilakukan }\end{array}$ \\
\hline 4 & $\begin{array}{l}\text { masih menggunakan } \\
\text { pompa electric }\end{array}$ & $\begin{array}{l}\text { terdapat kandungan } \\
\text { bahan kimia }\end{array}$ & $\begin{array}{l}\text { penyedotan bahan } \\
\text { kimia dengan } \\
\text { pompa angin atau } \\
\text { hydrolic }\end{array}$ \\
\hline 5 & $\begin{array}{l}\text { kurangnya } \\
\text { pemeriksaan sistem } \\
\text { bahan bakar }\end{array}$ & $\begin{array}{l}\text { sistem bahan bakar } \\
\text { masih terbuka }\end{array}$ & $\begin{array}{l}\text { dilakukan } \\
\text { pemeriksaan dan } \\
\text { perbaikan sistem } \\
\text { bahan bakar }\end{array}$ \\
\hline 6 & $\begin{array}{l}\text { kurangnya perbaikan } \\
\text { bagian bawah air }\end{array}$ & $\begin{array}{l}\text { kerusakan bagian } \\
\text { bawah air kapal }\end{array}$ & $\begin{array}{l}\text { dilakukan } \\
\text { perbaikan bagian } \\
\text { bawah air }\end{array}$ \\
\hline 7 & $\begin{array}{l}\text { tidak mengunakan } \\
\text { software pendeteksi } \\
\text { gempa sejak dini }\end{array}$ & terjadi gempa & $\begin{array}{l}\text { menggunakan } \\
\text { earthquake alert }\end{array}$ \\
\hline
\end{tabular}




\begin{tabular}{|c|c|c|c|}
\hline 8 & $\begin{array}{l}\text { tidak mengunakan } \\
\text { software pendeteksi }\end{array}$ & terjadi tsunami & $\begin{array}{l}\text { menggunakan } \\
\text { earthquake alert }\end{array}$ \\
\hline 9 & $\begin{array}{l}\text { gempa sejak dinı } \\
\text { belum menggunakan } \\
\text { alat prediksi arus air }\end{array}$ & arus kencang & $\begin{array}{l}\text { menggunakan } \\
\text { ADCP }\end{array}$ \\
\hline No & & Akar Permasalahan & Tindakan Preventif \\
\hline 10 & $\begin{array}{l}\text { tidak dilakukan } \\
\text { analisa kondisi } \\
\text { tangki }\end{array}$ & $\begin{array}{l}\text { terjadi kebocoran } \\
\text { pada tangki kapal }\end{array}$ & $\begin{array}{l}\text { dilakukan analisa } \\
\text { kondisi tangki } \\
\text { kapal }\end{array}$ \\
\hline 11 & $\begin{array}{l}\text { belum menggunakan } \\
\text { SDM yang } \\
\text { berpengalaman }\end{array}$ & $\begin{array}{l}\text { kesalahan } \\
\text { perhitungan } \\
\text { pemasangan air } \\
\text { bag }\end{array}$ & $\begin{array}{l}\text { menggunakan } \\
\text { SDM } \\
\text { berpengalaman }\end{array}$ \\
\hline 12 & $\begin{array}{l}\text { tidak disediakan } \\
\text { kompresor cadangan }\end{array}$ & $\begin{array}{l}\text { kerusakan } \\
\text { kompressor udara } \\
\text { dalam proses } \\
\text { pengapungan kapal }\end{array}$ & $\begin{array}{l}\text { menyediakan } \\
\text { kompressor } \\
\text { cadangan }\end{array}$ \\
\hline 13 & $\begin{array}{l}\text { meeting tidak } \\
\text { dilakukan secara } \\
\text { intensif }\end{array}$ & $\begin{array}{l}\text { kelalaian operator } \\
\text { dalam proses } \\
\text { pengapungan kapal }\end{array}$ & $\begin{array}{l}\text { dilakukan meeting } \\
\text { sebelum dan } \\
\text { sesudah memulai } \\
\text { pekerjaan }\end{array}$ \\
\hline 14 & $\begin{array}{l}\text { tidak dilakukan } \\
\text { rigging pada kapal }\end{array}$ & $\begin{array}{l}\text { perubahan struktur } \\
\text { kapal saat proses } \\
\text { pengapungan }\end{array}$ & $\begin{array}{l}\text { dilakukan rigging } \\
\text { kapal pada saat } \\
\text { peniupan udara } \\
\text { dalam tangki kapal }\end{array}$ \\
\hline 15 & $\begin{array}{l}\text { kurangnya personel } \\
\text { pengawas }\end{array}$ & $\begin{array}{l}\text { pelaksanaan } \\
\text { pengapungan tidak } \\
\text { sesuai SOP }\end{array}$ & $\begin{array}{l}\text { perlu adanya } \\
\text { pengawasan pada } \\
\text { saat proses } \\
\text { pengapungan kapal }\end{array}$ \\
\hline 16 & $\begin{array}{l}\text { tidak dilakukan } \\
\text { analisa kerusakan } \\
\text { badan kapal }\end{array}$ & $\begin{array}{l}\text { kerusakan badan } \\
\text { kapal saat } \\
\text { diapungkan }\end{array}$ & $\begin{array}{l}\text { dilakukan analisa } \\
\text { kerusakan badan } \\
\text { kapal }\end{array}$ \\
\hline 17 & $\begin{array}{l}\text { SDM yang } \\
\text { digunakan blm } \\
\text { berpengalaman }\end{array}$ & $\begin{array}{l}\text { kapasitas crane } \\
\text { tidak memenuhi }\end{array}$ & $\begin{array}{l}\text { menggunakan } \\
\text { SDM } \\
\text { berpengalaman }\end{array}$ \\
\hline 18 & $\begin{array}{l}\text { tidak dilakukan } \\
\text { pembersihan lumpur }\end{array}$ & $\begin{array}{l}\text { tidak dilakukan } \\
\text { pembersihan } \\
\text { lumpur }\end{array}$ & $\begin{array}{l}\text { perlu adanya } \\
\text { pembersihan } \\
\text { endapan yang } \\
\text { terdapat pada kapal }\end{array}$ \\
\hline 19 & $\begin{array}{l}\text { tidak dilakukan } \\
\text { analisa kondisi } \\
\text { endapan }\end{array}$ & $\begin{array}{l}\text { kondisi kapal } \\
\text { terdapat endapan } \\
\text { lumpur }\end{array}$ & $\begin{array}{l}\text { perlu analisa } \\
\text { kondisi endapan } \\
\text { pada kapal } \\
\text { tenggelam }\end{array}$ \\
\hline
\end{tabular}

Pada Tabel 3 dijelaskan tindakan preventif dari masingmasing akar permasalahan yang didapat. Akar-akar permasalahan ini mendasari terjadinya risiko yang menyebabkan kegagalan pada proses pengapungan kapal. Oleh sebab itu, tindakan preventif diberikan untuk mengurangi ataupun mencegah terjadinya risiko kegagalan.

\section{Implementasi RBI}

Kondisi pembiayaan proses pengapungan kapal saat ini masih menggunakan metode konvensional menggunakan pendekatan harga pasar dengan mempertimbangkan metode yang digunakan oleh perusahaan salvage. Pembiayaan hanya memperhitungkan biaya yang tampak (material dan jasa) sehingga apabila terjadi pembengkakan biaya diakibatkan kegagalan proses tidak bisa dilakukan revisi pada kontrak yang telah disepakati antara pemilik kapal dan perusahaan. Dimana biaya yang timbul akibat kegagalan sangat tinggi sehingga perusahan penyelamatan mengalami kerugian.

$$
\text { Tabel } 4 .
$$

Biaya Total Proses Pengapungan

\begin{tabular}{lccc}
\hline \hline \multicolumn{2}{c}{\begin{tabular}{c} 
Total Biaya \\
\multicolumn{2}{c}{ Pengapungan (Juta) }
\end{tabular}} & $\begin{array}{c}\text { Usia Tenggelam } \\
\text { Dibawah 10 tahun } \\
\text { (Juta) }\end{array}$ & $\begin{array}{c}\text { Usia Tenggelam } \\
\text { Diatas 10 tahun } \\
\text { (Juta) }\end{array}$ \\
\hline Personel & 4,550 & 5,027 & 5,121 \\
kapal & 6,425 & 6,425 & 6,425 \\
\hline \hline
\end{tabular}

\begin{tabular}{lccc}
\hline \hline Peralatan & 1,020 & 1,205 & 1,205 \\
consumable & 170 & 170 & 170 \\
operational & 1,440 & 1,455 & 1,444 \\
TOTAL & 13,605 & 14,282 & 14,365 \\
\hline \hline
\end{tabular}

Jumlah keseluruhan biaya yang harus dikeluarkan pada pekerjaan pengapungan kapal tenggelam adalah sebesar Rp. 13.605.000.000. dari keseluruhan total biaya yang dikeluarkan biaya untuk kapal adalah biaya terbesar yang harus dikeluarkan yaitu sebesar 6,4 M. Untuk biaya personel menempati posisi kedua terbesar setelah kapal yaitu sebesar 4,5 M dan utnuk biaya peralatan dan operasional memerlukan biaya yang tidak jauh berbeda yaitu sebesar $1 \mathrm{M}$ lebih. Biaya yang paling kecil dari total keseluruhan biaya yg harus dikeluarkan adalah biaya consumable yaitu sebesar 170 juta.

Biaya mitigasi yang terhitung dibandingkan dengan biaya proses pengangkatan kapal tenggelam dari masing-masing usia tengggelamnya kapal menghasilkan 4,98\% yaitu sebesar 670 juta rupiah. untuk kapal dengan usia tenggelam dibawah 10 tahun dan 5,58\% dengan besar 760 juta rupiah untuk kapal dengan usia tenggelam diatas 10 tahun dari total biaya pekerjaan. Perencanaan biaya pekerjaan pengapungan dilakukan bedasarkan analisis biaya reparasi dari kapal yang menjadi objek studi

\section{KESIMPULAN DAN SARAN}

1. Risiko yang dapat mengakibatkan kegagalan pada proses pengapungan kapal tenggelam adalah badan kapal patah, kapal terbalik, kapal terjatuh dan kapal meledak.

2. Rekomendasi preventif khusus untuk mengurangi dampak terjadinya kegagalan pengapungan kapal tenggelam adalah dengan penambahan jumlah personel pengapungan, pemeriksaan kondisi kapal, penggunaan peralatan dan aplikasi khusus, penggunaan SDM berpengalaman, penambahan alat pengapungan, peningkatan koordinasi, mempertahankan struktur kapal dan pembersihan endapan yang ada pada kapal.

3. Pendekatan metode Risk Based Inspection diimplementasikan dengan mengidentifikasi risiko yang terdapat pada kerangka kerja. Akar permasalahan yang didapatkan diberi tingkatan risiko dengan menggunakan matriks risiko. Risiko diberikan tindakan preventif untuk mengurangi dampak terjadinya risiko. Biaya mitigasi untuk kapal dengan lama tenggelam dibawah 10 tahun sebesar 4,98\% dan untuk kapal dengan lama tenggelam diatas 10 tahun sebesar 5,58\% dari total biaya proses pengapungan kapal tenggelam.

\section{DAFTAR PUSTAKA}

[1] A. 581, Risk-Based Inspection Base Resource Document. Washington D.C: American Petroleum Institute, 2008.

[2] Z. A. Fadhilah, "Perkiraan Perhitungan Nilai Penyelamatan Pada Musibah Kecelakaan Kapal (studi kasus: kecelakaan Kapal Di indonesia)," Institut Teknologi Sepuluh Nopember, 2010.

[3] M. Haris, "Kajian Manajemen Fault Tree Analysis. Diambil dari Kajian Manajemen Fault Tree," 2016. [Online]. Available: http://muh-haris.blogspot.co.id/2015/10/ html .

[4] L. W. Baroto, "Studi Implementasi Risk Based Inspection (RBI) Untuk Perencanaan Biaya Reparasi Kapal," Institut Teknologi Sepuluh Nopember, 2013. 